\title{
Sovereign Default and Economic Performance in Oil-Producing Economies
}

Maria A. Arias, Senior Research Associate

Paulina Restrepo-Echavarria, Economist

wings in oil prices affect many decisions of oilproducing countries, such as how much oil to pump and how much to borrow or lend. These decisions in turn affect their rate of growth and the likelihood they will pay their debts. Thus, it is important to understand how sovereign risk of oil producers varies with oil prices (see Hamann, Mendoza, and Restrepo-Echavarria, 2016, hereafter HMR).

Although most people assume big oil-producing countries do not hold significant public debt, HMR find that they do. Figure 1 shows the average public debt for the top 25 net oil exporters from 1979 to 2010 , which ranges from 8 to 170 percent of GDP, with an average of about 50 percent. These are not negligible numbers. HMR show the average duration of a default episode for the same set of countries (Figure 2). The episodes range from zero to 25 years, with only 8 of the 25 countries never having had a default episode. ${ }^{1}$ Because important oil-producing countries do hold public debt and have defaulted on it, it would be useful to understand how oil reserves and production affect sovereign risk and macroeconomic performance in these economies.

Using data from the Institutional Investor Country Credit ratings for 1979-2010 as a proxy for sovereign risk, HMR study how oil reserves, oil production, oil prices, and public debt levels relate to sovereign default risk. The ratings are based on a survey of leading international bankers, who rate each country on a scale of 0 to 100 (where 100 represents maximum creditworthiness). The individual bank ratings are then weighted according to that bank's global exposure and level of sophistication of the analysis.

The HMR results show that a larger share of oil in GDP and a higher oil price reduces the perceived risk for a given oil-producing country because higher oil output and higher oil prices allow the public sector to support higher levels of public debt. Second, perhaps surprisingly, however, a higher level of oil reserves actually increases a country's perceived risk in the long

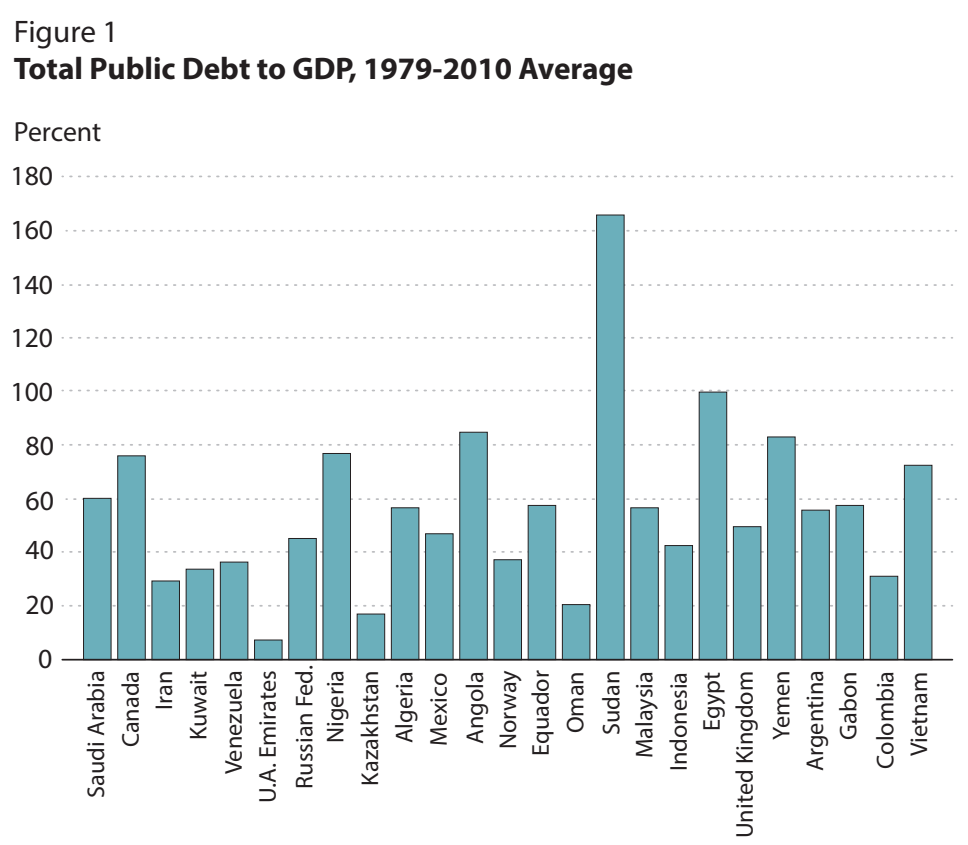

SOURCE: IMF World Economic Outlook and World Bank World Development Indicators.

Figure 2

Default Episodes, 1979-2010

Years in Default (years in sample $=32$ )

25

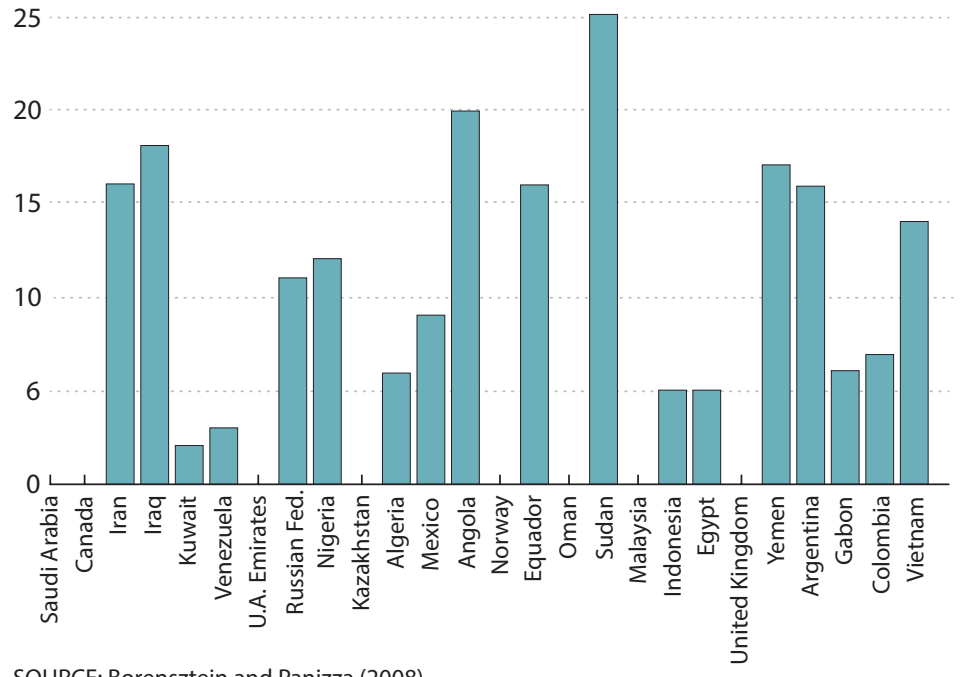

SOURCE: Borensztein and Panizza (2008). 


\section{ECONOMIC Synopses}

run. ${ }^{2}$ Although counterintuitive, the authors argue that this finding reflects the fact that a country with a large stock of oil may be able to withdraw from the global financial system more easily, making default more appealing. Moreover, during default episodes, most oil-producing countries increase oil production. This evidence suggests that a country in default and excluded from international financial markets pumps more oil to counter the financial consequences of default.

\section{Because oil-producing countries do hold public debt and do default, we must understand how oil reserves and production affect risk and economic performance.}

The authors find that, in the long run, a country's average risk rating is 0.2 percent higher on average when either its oil GDP or non-oil GDP increases by 1 percent. Thus, the perception of risk declines in either circumstance. The authors also find statistical evidence suggesting that an increase in oil reserves also reduces perceived country risk. Moreover, higher total public debt significantly worsens the risk rating. Finally, changes in net foreign assets have little to no effect on risk ratings in the short run when controlling for oil reserves.
HMR explore the relationship between overall economic performance and oil price swings. Their findings highlight how oil-price volatility affects oil-producing countries' incentives to produce oil and manage debt: Oil-price upswings increase oil extraction and GDP growth rates, improve trade balances and current accounts, lower sovereign risk perception, and reduce the likelihood of default episodes. The contrary is true for oil-price downswings.

\section{Notes}

${ }^{1}$ The default episodes are from Borensztein and Panizza (2008), who use data from Standard and Poor's. As they note, Standard and Poor's generally defines sovereign default as the failure to meet a principal or interest payment on the due date (or within the specified grace period) as specified in the original terms of the debt issue.

${ }^{2}$ Oil reserves and oil production data are from the U.S. Energy Information Administration.

\section{References}

Borensztein, Eduardo and Panizza, Ugo. "The Costs of Sovereign Default." Working Paper 08/238, International Monetary Fund, October 2008.

Hamann, Franz; Mendoza, Enrique. G. and Restrepo-Echavarria, Paulina. "Commodity Prices and Sovereign Default: A New Perspective on the Harberger-Laursen-Metzler Effect." Unpublished manuscript, 2016. 